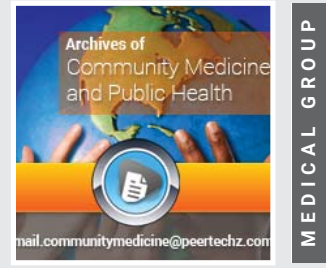

\title{
COVID-19: An unprecedented crisis that needs an extraordinary response
}

Received: 20 April, 2020
Accepted: 24 April, 2020

Published: 25 April, 2020

*Corresponding author: Tabish SA, FRCP, FACP, MHA (AIIMS), Doctorate in Educational Leadership, Sher-iKashmir Institute of Medical Sciences, Srinagar, India, E-mail: amintabish@gmail.com

https://www.peertechz.com

\section{Check for updates}

\section{Tabish SA*}

FRCP, FACP, MHA (AIIMS), Doctorate in Educational Leadership, Sher-i-Kashmir Institute of Medical

Sciences, Srinagar, India

Today we are confronted with an unprecedented crisis world has never experienced before. Coronavirus pandemic has affected 213 countries, areas and territories. With 3,139,000 cases and 218,020 deaths globally (as on 29 April, 2020), there is no stop to the spread. The USA, Italy, Spain, France, UK, Germany, Belgium, Turkey and Iran have more cases and deaths than rest of the countries. The pandemic has been one of the greatest global collective failure.

Globalisation, ever-increasing, international travel, accelerating urbanisation, indiscriminate use of antibiotics and consequent resistance developed by microbes, poor public health facilities including surveillance systems, growing inequalities, change in behavioural and social patterns, and environmental degradation (humanity has dramatically affected the global biosphere in deep and complex ways). are some of the important causes for emergence and re-emergence of infectious diseases. HIV, Hantavirus, SARS, H1N1, H5N1, Ebola, Zika, Nipah are some of the emergent infections and tuberculosis as re-emerging infection during the last four decades.

Worsening crisis with devastating effects on the world of work, the COVID-19 pandemic has intensified and expanded in terms of its global reach, with huge impacts on public health and unprecedented shocks to economies and labour markets. It is the worst global crisis since the Second World War. The global economy has hit the worst recession as a result of the pandemic. The employment impacts of COVID-19 are deep, far-reaching and unprecedented [1].

Some nations have done exceptionally well in responding to the pandemic. South Korea did extensive testing, identifying the infected people and their contacts and putting them in quarantine spread. Vietnam practiced extensive quarantining measures which helped in limiting the number of cases. Taiwan's success was a result of early response by way of border controls and wearing of mask. It has become one of the most effective countries in arresting the spread of the pandemic. Singapore and Hong Kong also managed the pandemic effectively.

Some countries have not done enough to contain the spread of Disease. The USA, UK, and India were initially slow that resulted in fast spread. There have also been problems of supply chain (inadequate PPEs, ventilators, oxygen and drugs) and shortage of health facilities like ICUs, beds, etc. Quarantine centres were either inadequate or having unhygienic conditions.

Humans have been battling viruses since before our species had even evolved into its modern form. Vaccines and antiviral drugs for some infectious diseases have allowed us to keep infections from spreading widely. Only Smallpox has been eradicated. Battle against viral infections has not been won so far by humans. The 12 worst killers, based on the likelihood that a person will die if they are infected with one of them, the sheer numbers of people they have killed, and whether they represent a growing threat include: Marbug, Ebola, Rabies, HIV, Smallpox, Hantavirus, Influenza, Dengue, Rota Virus, SARS-CoV, SARS CoV-2, MERS-CoV, are considered as twelve deadliest viruses on earth [2].

Medical science has come a long way in improving our basic understanding of the origin and effect of most infectious diseases. However, science has proven far less adept at recognizing and effectively dealing with the factors that facilitate the spread of viruses. 
There are instances of stigma being attached to COVID-19 patients. This is unacceptable in a civilised society, The ones who recover from the infection with a feeling of victory against the enemy are lucky. Why should "scared" stigmatize the "secured". COVID-19 can infect anyone, anywhere, anytime. Just like any other disease.

The worst economic fallout since the Great Depression is anticipated. The International Monetary Fund (IMF) on April 14, 2020 slashed growth forecast for the Indian economy, projecting a GDP growth of 1.9 percent in 2020. According to its World Economic Outlook for 2020-2021 the global economy is projected to contract sharply by-3 percent in 2020 . The U.S. economy is projected to shrink this year by 5.9 percent and the euro area by 7.5 percent. The cumulative loss to global GDP over 2020 and 2021 from the pandemic crisis could be around 9 trillion dollars. For the year 2020, growth in advanced economies is projected at -6.1 percent. Emerging market and developing economies are projected to have negative growth rates of -1.0 percent in 2020 , and $\mathbf{- 2 . 2}$ percent. According to its World Economic Outlook for 2020-2021 the global economy is projected to contract sharply by-3 percent in 2020 . The U.S. economy is projected to shrink this year by 5.9 percent and the euro area by 7.5 percent.

Worldwide, two billion people work in the informal sector. Both developing and developed economies are failing the catastrophic challenge. According to The International Labour Organization (United Nations) report 'ILO Monitor $2^{\text {nd }}$. Edition COVID-19 and the World of work', describing the COVID-19 pandemic as the worst global crisis since World War II, about 400 million workers in informal economy in India may sink into poverty due to COVID pandemic which will have catastrophic consequences and is expected to wipe pout 195 million fulltime jobs or 6.7 percent of working hours globally in the second quarter of current year. The lockdown and social distancing has pushed the weaker sections of the society to wall. Many people have lost jobs. Those working in the informal sector are most vulnerable. Migrant workers, daily wagers and casual labourers are struggling to make their both ends meet. Those living in urban slums are facing most difficult times. Deprivation of social security, food, clothing and shelter is likely to result in social unrest and food riots. Disruptions to the economies caused by the pandemic is likely to wipe-out 6.7 percent of working hours (195 million jobs) globally. Nearly 81 percent (four out of five) in the worldwide workforce of 3.3 billion has been affected by the pandemic. Governments have to act fast and decisively. Decisions about these most vulnerable populations will shape the future of humanity at large. Solidarity both at international and national level is crucial to overcome this global crisis of unprecedented nature in the entire human history. Timely actions are of paramount importance to save the vulnerable people from catastrophic consequences. Governments have to respond to the challenges of growing pandemic and save lives that may otherwise perish. Appropriate policy measures and strategic planning is required to focus on employment and income. ${ }^{1}$ India's economy may be heading for its first full-year contraction in more than four decades. There will be indirect effects such as the persistence of the public fear factor even after the lockdown ends. There lockdown in India will result in a direct output loss of more than $8 \%$ over that time. Moreover, there will also be an impact on livelihoods of the unorganized workforce, and a sharp increase in corporate and banking sector stress, which are likely to further weigh on growth.

Random testing should be done aggressively and strategically as testing only will guide us about pockets of hotspots. Virus will live in the community for a long time. Moreover, only letting herd immunity to develop, we have to face surge of symptomatic elderly patients with severe disease that will overstretch health systems likely to lead to collapse of public health facilities. We have to dodge the virus. Till good proportion of younger generation develops immunity.

People and invading microorganisms evolve together: people gradually become more resistant, and the microorganisms become less virulent. The modern world is becoming a viral superhighway. Left unchecked, today's emerging diseases can become the endemic diseases of tomorrow. The world still had a window of opportunity to avoid the virus becoming endemic The best way to tackle it is for the governments to act swiftly and forcefully to isolate it [3].

Use of Plasma of those who have recovered from COVID illness has generated some hope and it needs data from various places who are experimenting it. The results are still awaited.

Vaccine development is the only hope. It is going to take its time upto 18 months or so. Even if vaccine is made available, its affordability and accessibility is going to be a huge challenge at international as well as national levels.

The pandemic will alter the world forever. An economic slowdown, severe recession, plummeting revenue, increased expenditure, mounting debt, massive domestic crises and mental health issues (anxiety, depression, stress) could be the emerging challenges. There will be awakening of a new world order, a turning point in human history. Education system will experience transformation, more investment in public health will be a top priority for the governments. Collectively, we can respond to the challenge and reshape the future of humanity that is safe and secure.

\section{References}

1. ILO Monitor 2nd edition (2020) COVID-19 and the world of work. Link: https://bit.ly/3bCXz00

2. Harding A, Lanese N (2020) The 12 deadliest viruses on Earth. Live Science. Link: https://bit.ly/35bifda

3. Tabish SA (2003) Is world becoming a viral superhighway? Journal of Medical Sciences 6: 87-89. Link: https://bit.ly/2xZGTkB

Citation: Tabish SA (2020) COVID-19: An unprecedented crisis that needs an extraordinary response. Arch Community Med Public Health 6(1): 053-054 